\title{
Execution technique and pigment characteristics of Byzantine wall paintings of Anaia Church in Western Anatolia
}

\author{
Serap Demir, Kerem Şerifaki*, Hasan Böke \\ Architectural Restoration Department, Izmir Institute of Technology, 35430 Izmir, Turkey
}

\section{A R T I C L E I N F O}

\section{Keywords:}

Wall paintings

Byzantine period

Western Anatolia

Pigments

Multi-analytical investigation

\begin{abstract}
A B S T R A C T
In this study, material characteristics of wall paintings executed in 11th Century Byzantine Church located in archaeological site of Anaia (Turkey) were investigated to provide historical information of the painting techniques. For this purpose, physical, chemical and mineralogical compositions of the paintings were determined by X-Ray Diffraction, Fourier Transform Infrared spectroscopy, Scanning Electron Microscopy coupled with Energy Dispersive spectroscopy and Thermo-Gravimetric Analysis. Analysis results indicated that the paintings were executed using lime-secco technique. In this technique, pigments were mixed with lime and applied on a smooth plaster layer. Pigments used were mainly iron oxides for red, yellow and purple paintings, aluminosilicates such as celadonite for green paintings and lazurite for dark blue paintings.
\end{abstract}

\section{Introduction}

People have decorated the walls of the living places with paintings that reflect their feelings from the earliest beginnings to present. Wall paintings, together with mosaics, are the most common decorative elements in the Byzantine Architecture. Especially in the religious architecture they were used for artistic, spiritual and educational purposes. Depending on the artistic needs of the era, a variety in the painting techniques and materials used in the wall paintings are developed.

In Byzantine era, renderings of wall paintings consisted of two layers, arriccio (rough plaster) and intonaco (fine plaster). The main constituent of the renderings was a mixture of lime and sand or marble dust or sometimes brick aggregates (Mora et al., 1984). The pigments used were mostly natural substances and minerals such as charcoal and carbon black for black, azurite and rarely lapis lazuli for blue, terreverte or malachite for green, iron oxides, caput mortuum, cinnabar, minium, and umber for reddish brown. Gilding of the haloes and nimbuses were made with gold leaf on incised lines (Jeffreys et al., 2008).

Characteristics of wall paintings executed in Byzantine churches were determined to provide historical information and to decide the appropriate intervention methods of the paintings in some studies (Restle, 1969; Schwartzbaum, 1986; Daniilia et al., 2007; Daniilia et al., 2008; Bianchin et al., 2008; Hein et al., 2009; Pelosi et al., 2013; Pelosi et al., 2016; La Russa et al., 2016).

Among the studies, Hein et al. (2009) have studied the characteristics of Byzantine wall paintings of churches constructed in the tenth to fifteenth century, from the Mani peninsula, Greece. They indicated that the earthen pigments were mixed with lime water as a binding medium and then applied on a wet lime substrate.

The painting technique of St Stephen's wall paintings at Meteora from Byzantine to post-Byzantine period was studied by Daniilia et al. (2008). It was indicated that rough lime plaster layer (arriccio) consisted of yellow clay and straw pieces and fine plaster consisted of carbonated lime. In this study, eight earthen pigments were indicated in the execution of the painting colours.

The painting layer stratigraphy and chemical compositions of the binders and the pigments of Byzantine wall paintings in the Protaton Church (Greece) were determined by Daniilia et al. (2007). The experimental results demonstrated that the paintings were executed in both the true fresco and lime-painting techniques and earthen pigments were used in the painting.

The materials used in the preparation of plaster layers and paintings at Kariye Museum (İstanbul) were determined by Bianchin et al. (2008). The results of the study indicated that fresco technique was mainly used but secco was also employed with a tempera based on casein. The painting colours were developed by using natural and synthetic inorganic pigments.

Materials characteristics of the Byzantine wall paintings in the Tokalı Church in Cappadocia were studied by Schwartzbaum (1986). Results of the studies demonstrated that mainly red and green earth pigments were executed on a single layer of whitewash that act as a priming layer over the rock surface in the old church. In the new

\footnotetext{
* Corresponding author.

E-mail address: keremserifaki@iyte.edu.tr (K. Şerifaki).
} 
church, the use of red ochre, yellow ochre, green earth, carbon black, gypsum white and lapis lazuli over an intonaco composed of lime, river sand and straw was determined. On the intonaco a priming layer of white wash is present. Painting technique of the paintings were determined as fresco but sometimes finished in secco technique with lime and casein binders.

Wall paintings of a group of churches from 6th to 13th centuries A.D. in Cappadocia was studied by Pelosi et al. (2013). Gypsum plaster with traces of organic materials in the churches that belong to 6th-7th centuries and lime plaster with traces of organic material and a thin setting layer of gypsum in the churches that belong to 13th century were determined. Colours obtained from hematite, red lead, lead white, lead oxide, goethite, carbon black, green earth, ultramarine blue, jarosite and indigo constitutes the palette of the paintings.

Mortars and wall paintings of Forty Martyrs Church in Cappadocia were studied by Pelosi et al. (2016) and La Russa et al. (2016). Mortars used in the church are hydraulic due to the use of volcanic aggregates together with slaked lime (La Russa et al., 2016). A setting layer with high gypsum content is determined in wall paintings (La Russa et al., 2016; Pelosi et al., 2016).

Western Anatolia has had rich historical buildings and monuments from ancient times. In this study, material characteristics of historic paintings executed in a Byzantine church located in archaeological site of Anaia (Kadıkalesi) were determined (Fig. 1). Anaia was an upstate castle situated at the northwest of Davutlar Village in Kuşadas1, Aydın. The fortress was erected on a $25 \mathrm{~m}$ high hill from the sea level and $250 \mathrm{~m}$ away from the sea. Scientific excavations and surface investigations of the site were started at 2001. Archaeological findings during the excavations demonstrated that the castle was erected on a tumulus composed of six archaeological strata. The first settlement on the tumulus is dated to Late Chalcolithic Age (4000 BCE) (Akdeniz, 2007).

A monumental church-monastery complex dated to 11th century was uncovered in 2005 excavations. It is considered to have been a foundation donated by Konstantinos IX Monomachos, the emperor (1042-1055) (Mercangöz and Doğer, 2009). The complex is a magnificent edifice, competing with the huge buildings of Constantinapolis, with its monumental stone artworks and wall paintings (Mercangöz and Doğer, 2009). A great number of painting fragments were found during the excavations in the infill material which shows that once the Church has a comprehensive painting programme. However, at the present a small part of these paintings, which are slowly detaching from their support, are present and needs urgent measures before continuing excavations (Fig. 2).

In this study, material characteristics of the paintings were determined to provide historical information of the wall painting techniques and to choose the appropriate materials to be used in the conservation works of the paintings.

\section{Methods}

In this study, small pieces of wall paintings (Table 1) were provided by Prof. Dr. Zeynep Mercangöz, who is head of archaeological excavation team of Anaia. Samples that represent the palette of the paintings were chosen from the fragments found as detached in the infill material during the excavations.

The initial experimental study was to determine the stratigraphy and the execution technique of the paintings. For this determination, small samples of paintings were cut using a diamond saw (Buehler) and polished by using a diamond polisher and then coated with gold. The stratigraphy and the execution technique were determined using an EDS unit Philips XL30-SFEG Scanning Electron Microscope (SEM) on cross-sectional polished samples.

The bulk density and porosity of the plaster layer were determined by using standard RILEM test method (RILEM, 1980). They were determined by measuring dry, water saturated and hydrostatic weights.

Mineralogical compositions of fine plaster and painting layers were determined by X-ray diffraction (XRD) and Infrared Spectroscopy (FTIR) analysis. FT-IR analysis was also used for the determination of organic materials in the paintings (Zorba et al., 2006).

XRD analysis performed on powdered fine plaster and on the painting surfaces by using Philips X-Pert Pro X-ray Diffractometer operating at $40 \mathrm{kV}$ and $40 \mathrm{~mA}$, using $\mathrm{CuKa}$ radiation in the $5-70^{\circ}$ range with a scan speed of $1.6^{\circ}$ per min.

FT-IR analyses were carried out on powdered samples. For this analysis, a small amount of sample was taken by scalpel, ground in agate mortar and dispersed in $\mathrm{KBr}$ and pressed into pellets by about 10 tons $/ \mathrm{cm}^{2}$ pressure. Spectral measurements were carried out on a Perkin-Elmer System FT-IR Spectrum BX. Spectra were acquired between 4000 and $400 \mathrm{~cm}^{-1}$ with $4 \mathrm{~cm}^{-1}$ resolution. All spectra were collected in absorbance mode and corrected with respect to the spectrum of the $\mathrm{KBr}$.

Elemental compositions of the paint layers were determined by SEM-EDS analyses on the cross sections of the samples. The lime content in the fine plaster layer was evaluated by determining weight loss due to carbon dioxide released during the decomposition of carbonated lime by using a 51 Thermo-gravimetric analyzer (TGA). Analysis was carried out in static nitrogen atmosphere at a temperature range of $25-1000{ }^{\circ} \mathrm{C}$ with a heating rate of $10{ }^{\circ} \mathrm{C} / \mathrm{min}$.

\section{Results}

\subsection{Painting technique}

SEM analysis on cross-sectional samples indicated that paintings were composed of a fine plaster and a thin paint layer over the plaster layer. The execution techniques of the paintings were identified by examining the boundaries between fine plaster and paint layers. In most of the samples, plaster and paint layers are distinguishable with border
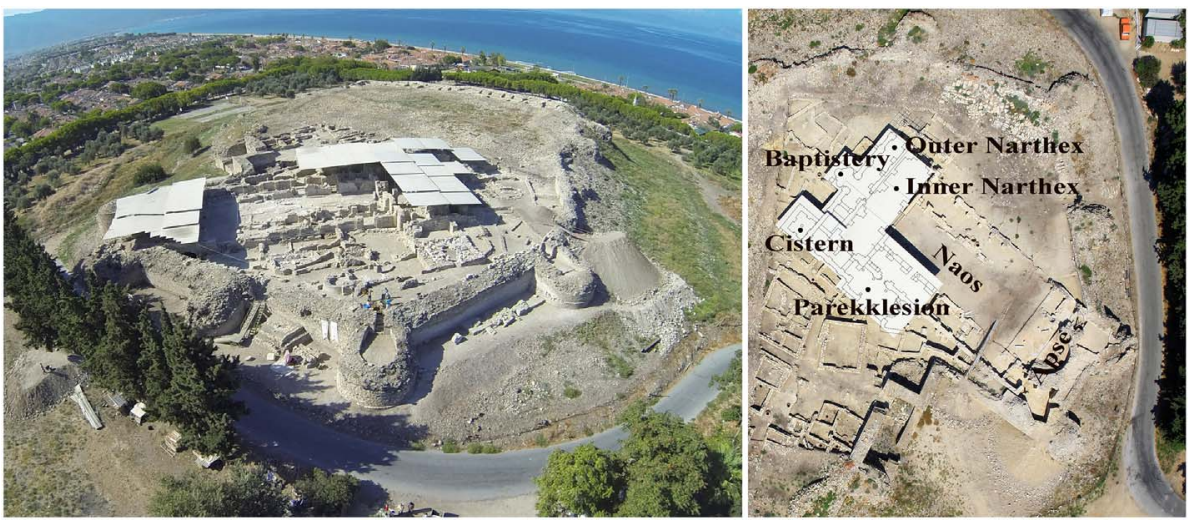

Fig. 1. Aerial views of Church and Monastery complex in Anaia (Anaia excavation archive, 2013). 

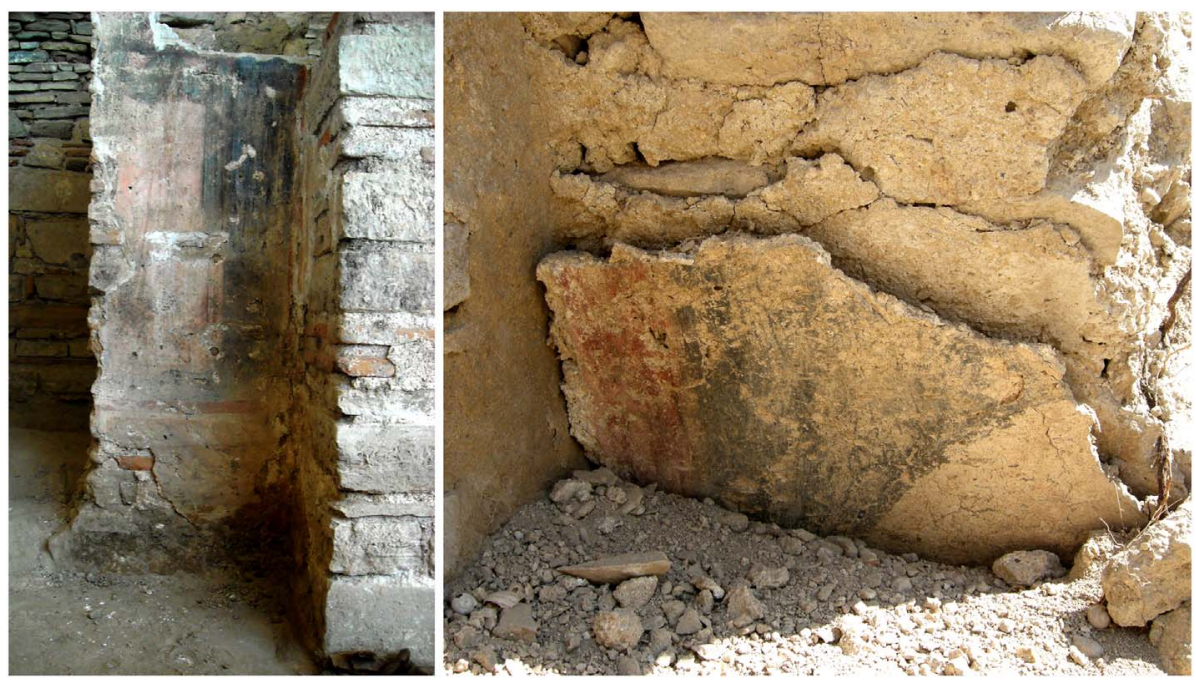

Fig. 2. Wall painting fragments on the walls of the narthex of the church.
Table 1

Painting samples.

Fine plaster (S. 1)
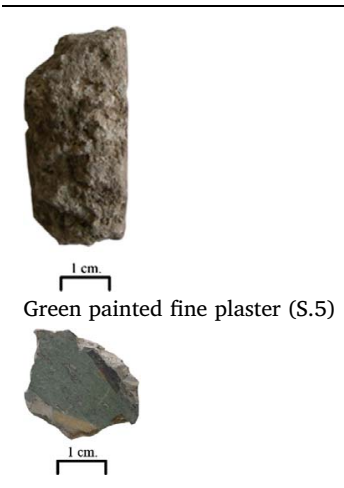

Dark blue painted fine plaster (S.6)

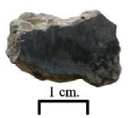

Blue Painted fine plaster (S.7)

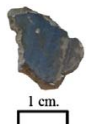

Red painted fine plaster (S.2)

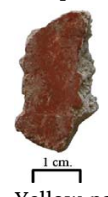

Yellow painted fine plaster (S.3)

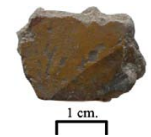

Purple painted fine plaster (S.4)

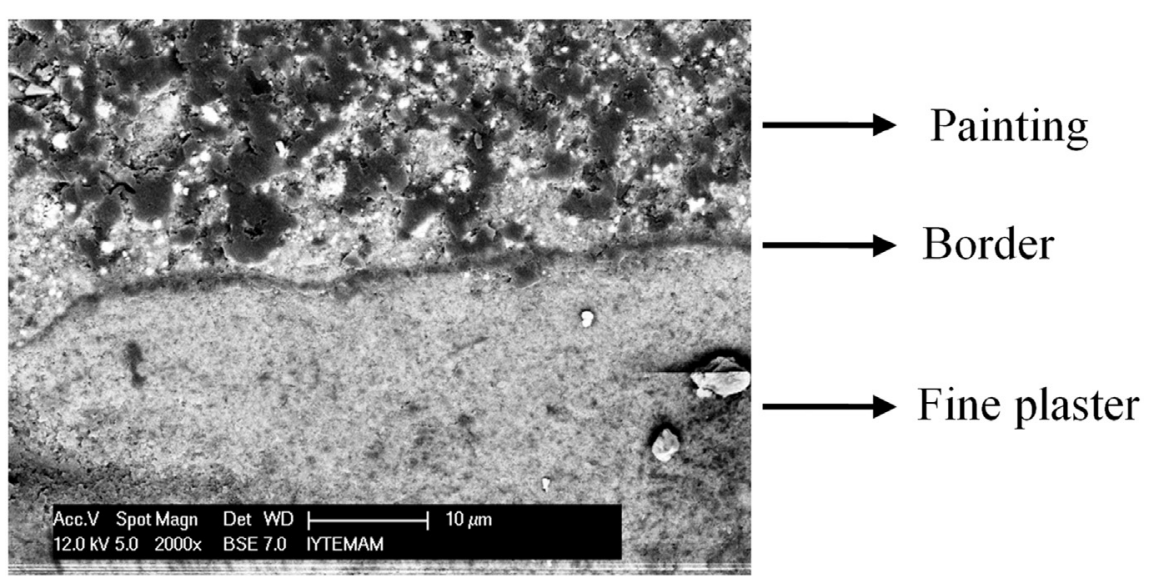

lines (Fig. 3). Distinguishable border lines may show that pigments were mixed with lime and then applied on dry plaster surfaces which can be called secco technique.

The use of organic materials in paintings such as casein, animal glue or eggs in this technique was investigated by FT-IR analysis. In the FTIR spectra of all the paint layers, organic materials were not detected. Hence, it can be said that organic materials were not used in the preparation of paint layers.

Secco paintings are generally fragile and poorly bonded to the fine plaster when compared to the fresco paintings. In this study, microcracks on the paint surface, blistering of binding layer and the detachment of the binding layer from the fine plasters were not observed. This can be explained due to the use of finest materials, techniques and craftsmanship in the execution of paintings.

\subsection{Characteristics of fine plaster layer}

Fine plaster layer has a smooth surface, a low density and high porosity values. Its density and porosity values were about $1.2 \mathrm{~g} / \mathrm{cm}^{3}$ and $40 \%$ by volume respectively. Its thickness was in the range from 1 to $1.5 \mathrm{~cm}$. The mineralogical composition of plaster layer was indicated by X-ray Diffraction (XRD) and FT-IR analyses. In the XRD pattern of the fine plaster layer, calcite and quartz peaks were observed (Fig. 4).

In its FT-IR spectrum, calcite bands at $1442,874,713,1795 \mathrm{~cm}^{-1}$ and a weak silica band at

$1079 \mathrm{~cm}^{-1}$ are observed (Fig. 5) (De Benedetto et al., 2002; Gadsden, 1975). These results indicated that fine plaster layer was mainly composed of calcium carbonate $\left(\mathrm{CaCO}_{3}\right)$ and quartz.

Fig. 3. BSE image of painting layers (S.2). 


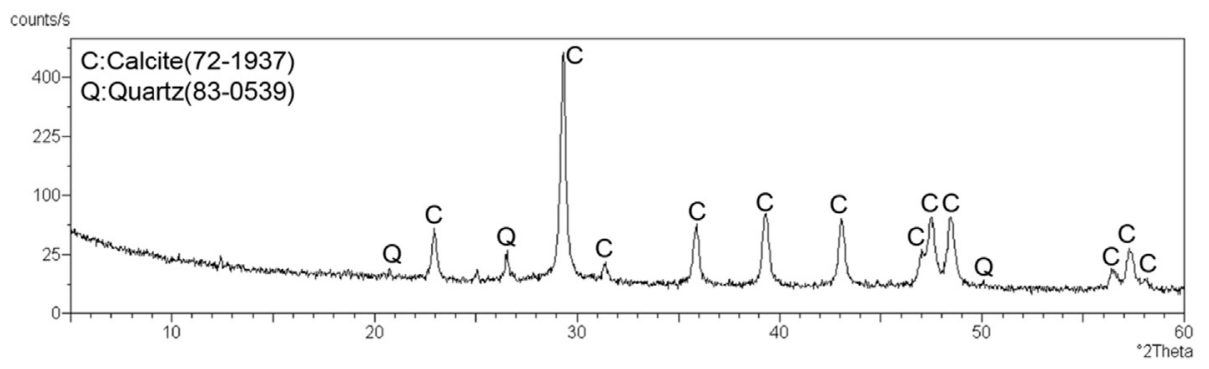

Fig. 4. XRD pattern of fine plaster layer (S.1).

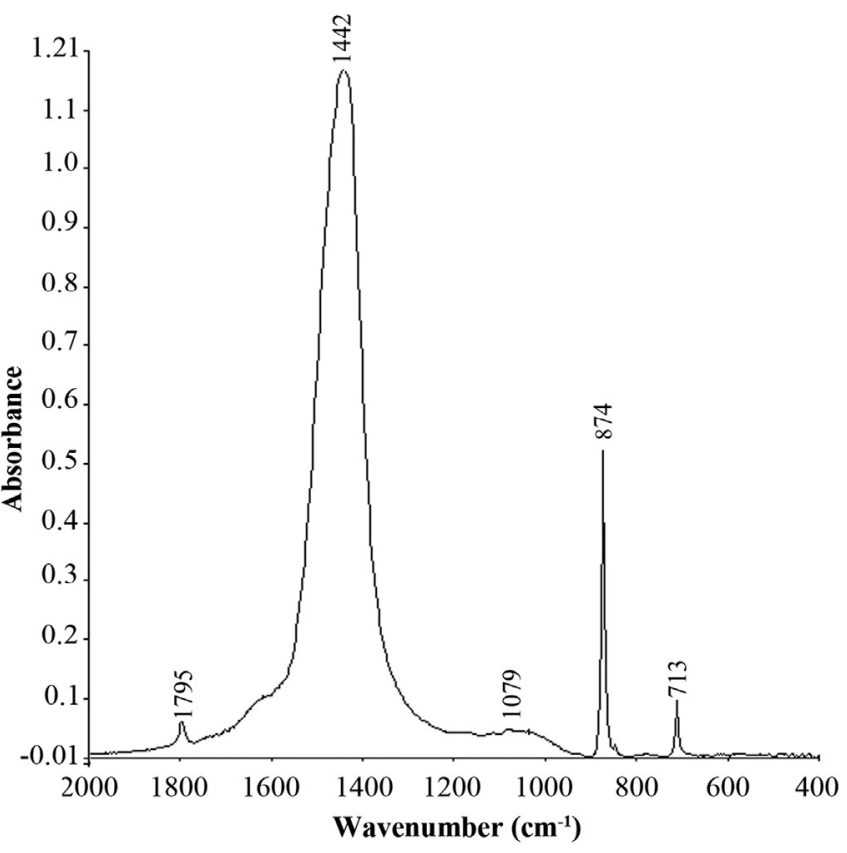

Fig. 5. FT-IR spectrum of fine plaster layer (S.1).

Observation of calcium carbonate is assigned to calcium lime and the weak silica band may be due to the quartz present in the calcite rock that the lime is produced from.

The percent composition of each constituent was determined by SEM-EDX and TGA analysis. SEM-EDS analysis indicated that plaster contains high amounts of calcium and low amounts of iron oxides, aluminium oxides and magnesium oxides (Table 2).

High amounts of calcium and low amounts of magnesium shows the use of calcium lime containing low amounts of magnesium as a binder in the preparation of the plaster. TGA analysis supported the SEM-EDS result. In the TGA graph, a $40 \%$ weight loss was observed at temperatures between $580{ }^{\circ} \mathrm{C}$ and $775{ }^{\circ} \mathrm{C}$ due to carbon dioxide driven from the carbonated lime (Fig. 6). This loss shows the use of nearly $90 \%$ lime in the preparation of plaster. The use of lime as binder in plaster layer was similar to some of those in Greece (Daniilia et al., 2007; Brysbaert, 2008; Hein et al., 2009).

\subsection{Characteristics of paint layers}

The execution techniques and thicknesses of the paint layers on the fine plasters were indicated by SEM analysis. Their mineralogical and chemical compositions were determined by XRD, FT-IR and SEM-EDS analyses.

\subsubsection{Red colored painting}

SEM analyses demonstrated that red painting was executed in the secco technique with lime solution. The thickness of the painting layer was about $70 \mu \mathrm{m}$ (Fig. 7a). In the FT-IR analysis of red paintings, calcite bands at 2515, 1797, 1430, $875 \mathrm{~cm}^{-1}, \mathrm{HCO}_{3}{ }^{-}$band at $1627 \mathrm{~cm}^{-1}$, silica bands at between $1029 \mathrm{~cm}^{-1}$, doublet bands of quartz at $799-775 \mathrm{~cm}^{-1}$ and characteristic bands of iron oxide at $546,471 \mathrm{~cm}^{-1}$ and 1154 are observed (Gadsden, 1975) (Fig. 7b). Its mineralogical composition as determined by XRD analysis indicated that it was composed of calcite, quartz and hematite minerals (Fig. 7c). In the SEM - EDS analyses, parallel to the XRD and FT-IR analysis results, mainly iron $(\mathrm{Fe})$, silicon $(\mathrm{Si})$, calcium $(\mathrm{Ca})$ and aluminium $(\mathrm{Al})$ were present in the composition of the red painting (Table 2). Based on the XRD, FT-IR and SEM-EDS analysis, it can be concluded that in the execution of the red painting, hematite $\left(\mathrm{Fe}_{2} \mathrm{O}_{3}\right)$ was used as red pigment and mixed with lime water and then applied to dry fine plaster layer.

It is known that hematite is the most widespread iron mineral and it has been used as a red paint pigment since prehistoric times (Mora et al., 1984). In recent studies, its use as a red pigment in the wall paintings of Byzantine churches in Greece and in Cappadocia (Daniilia et al., 2008; Pelosi et al., 2013; Pelosi et al., 2016) was also noticed.

\subsubsection{Yellow colored painting}

SEM analysis indicated that yellow painting was executed in the secco technique with lime solution (Fig. 8a). The thickness of the paint layer was about $25 \mu \mathrm{m}$. In the FT-IR spectrum of the yellow colored paintings, calcite bands at 2518, 1794, 1437, 875, $713 \mathrm{~cm}^{-1}$, HCO3band at $1627 \mathrm{~cm}^{-1}$, a distinctive peak of magnesite $(\mathrm{MgCO})$ from calcite at $728 \mathrm{~cm}^{-1}$, silica at $1036 \mathrm{~cm}^{-1}$, hematite at $470 \mathrm{~cm}^{-1}$ and $519 \mathrm{~cm}^{-1}$ were observed (Fig. 8b). In their XRD patterns, the strong

Table 2

Chemical compositions of paintings.

\begin{tabular}{|c|c|c|c|c|c|c|c|}
\hline \multirow[t]{2}{*}{ Samples } & \multicolumn{7}{|l|}{ Oxides (\%) } \\
\hline & $\mathrm{Na}_{2} \mathrm{O}$ & $\mathrm{MgO}$ & $\mathrm{Al}_{2} \mathrm{O}_{3}$ & $\mathrm{SiO}_{2}$ & $\mathrm{~K}_{2} \mathrm{O}$ & $\mathrm{CaO}$ & $\mathrm{Fe}_{2} \mathrm{O}_{3}$ \\
\hline Fine Plaster (S.1) & $2.1 \pm 1.3$ & $3 \pm 1.1$ & $4 \pm 0.5$ & $8 \pm 2.6$ & $1.1 \pm 0.2$ & $81.7 \pm 1.8$ & N.D. \\
\hline Red painting (S.2) & $1.0 \pm 0.1$ & $2.3 \pm 0.3$ & $5.6 \pm 0.5$ & $29.0 \pm 2.0$ & $1.3 \pm 0.2$ & $10.6 \pm 3.5$ & $50.3 \pm 0.9$ \\
\hline Yellow painting (S.3) & $2.2 \pm 0.9$ & $10.1 \pm 0.9$ & $11.4 \pm 1.7$ & $28.6 \pm 5.1$ & $1.6 \pm 0.1$ & $42.2 \pm 5.8$ & $3.9 \pm 1.1$ \\
\hline Purple painting (S.4) & $3.1 \pm 1.0$ & $6.3 \pm 0.4$ & $8.3 \pm 1.3$ & $17.9 \pm 4.5$ & $1.3 \pm 0.3$ & $60.1 \pm 4.8$ & $3.0 \pm 0.6$ \\
\hline Green painting (S.5) & $2.1 \pm 0.3$ & $5.7 \pm 0.7$ & $6.2 \pm 0.3$ & $24.1 \pm 1.2$ & $2.6 \pm 0.3$ & $54.1 \pm 2.0$ & $5.2 \pm 0.3$ \\
\hline Dark blue painting (S.6) & $3.1 \pm 0.9$ & $6.7 \pm 0.9$ & $8.8 \pm 1.2$ & $24.2 \pm 2.6$ & $1.9 \pm 0.4$ & $52.0 \pm 5.2$ & $3.5 \pm 0.4$ \\
\hline Blue painting (S.7) & $6.1 \pm 0.3$ & $6.7 \pm 0.3$ & $16.3 \pm 1.0$ & $36.8 \pm 2.8$ & $3.2 \pm 0.1$ & $26.9 \pm 4.2$ & $4.0 \pm 0.5$ \\
\hline
\end{tabular}

N.D.: Not detected. 


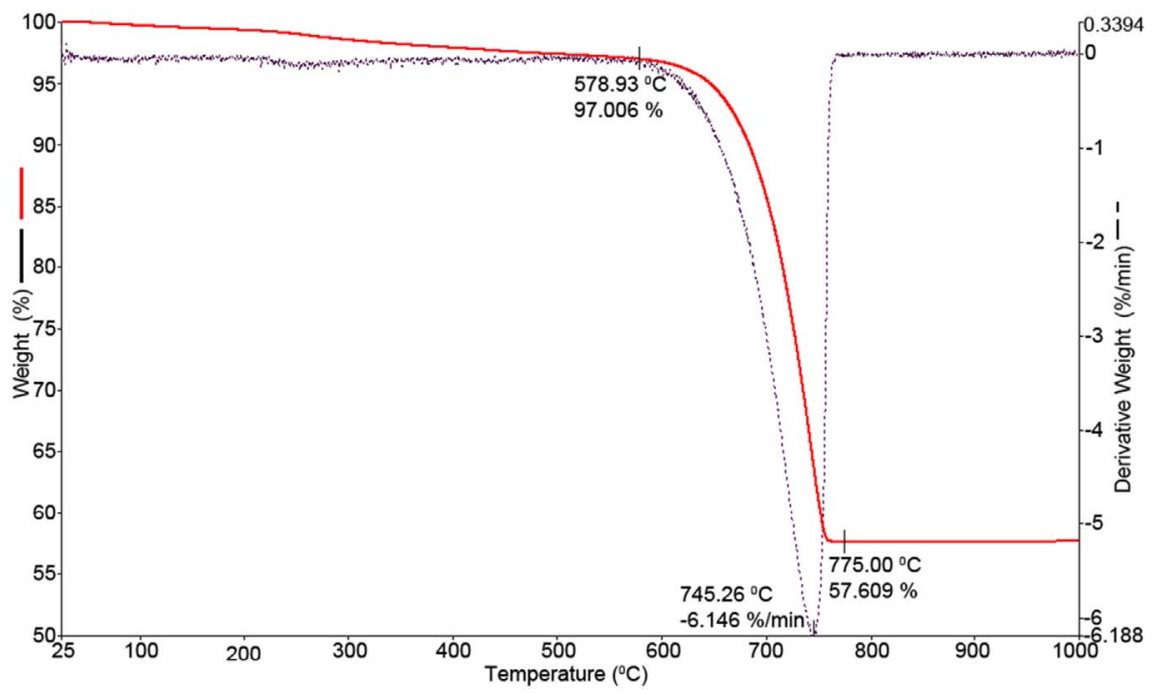

Fig. 6. TGA graph of fine plaster layer (S.1).

peaks of calcite, dolomite, and quartz and weak peaks of hematite and illite were observed (Fig. 8c).

The elemental composition of yellow paint layer indicated that it was mainly composed of calcium (Ca), magnesium $(\mathrm{Mg})$, silicon ( $\mathrm{Si}$ ), aluminium ( $\mathrm{Al}$ ) and moderate amounts of iron (Fe) (Table 2). It is known that yellow ochre consisted of iron oxide, silica and clay has been used as yellow pigment since ancient times (Hradil et al., 2003). Based on the XRD, FT-IR and SEM-EDS analysis results, it can be said that in the execution of the yellow painting, yellow ochre was used as pigment and mixed with dolomitic lime and then applied to the dry fine plaster layer.

In a recent study, the use of dolomitic lime in the binding medium of paintings has also been determined in Byzantine wall paintings (Hein et al., 2009). The use of dolomitic lime can be explained by its less shrinkage cracking properties than most of the common lime (Chever et al., 2010).

\subsubsection{Purple colored painting}

SEM analysis indicated that purple painting was executed in the secco technique on dry plaster surface with thickness of roughly $10 \mu \mathrm{m}$ (Fig. 9a). FT-IR analysis of the purple paint layer showed typical bands of the calcite and dolomite at 2515, 1798, 1625, 1428, 873, 727 and $713 \mathrm{~cm}^{-1}$ (Fig. 9b) (Gadsden, 1975). They can be differentiated by their characteristic bands observed at $727 \mathrm{~cm}^{-1}$ for dolomite and at $713 \mathrm{~cm}^{-1}$ for calcite (Mazzocchin et al., 2006). The infrared absorption band at $1035 \mathrm{~cm}^{-1}$ was due to silicate minerals and two characteristics bands of hematite at $471 \mathrm{~cm}^{-1}$ and $546 \mathrm{~cm}^{-1}$ were also indicated. The mineralogical composition of the purple paint determined by XRD analysis demonstrated that it was mainly composed of calcite, dolomite, quartz and hematite (Fig. 9c).

The elemental composition of paint layer was determined by SEMEDS analysis. In the SEM-EDS analyses, calcium (Ca) and magnesium $(\mathrm{Mg})$ due to carbonated lime binder, iron ( $\mathrm{Fe}$ ) due to pigments and $\mathrm{Al}$,

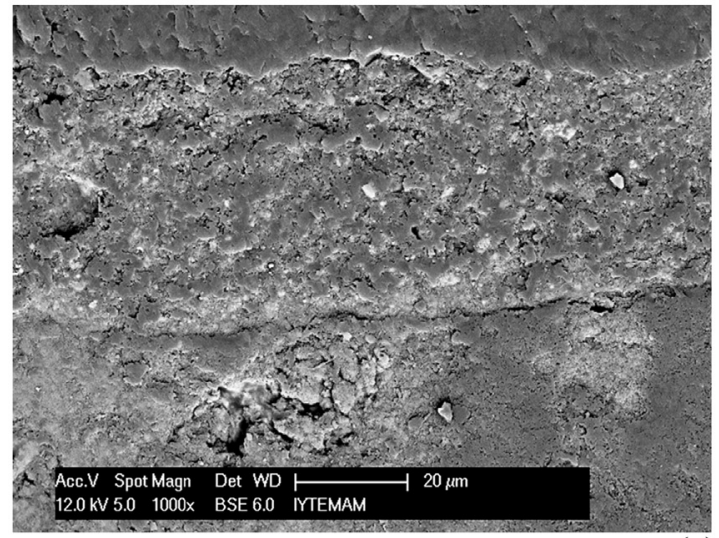

(a)

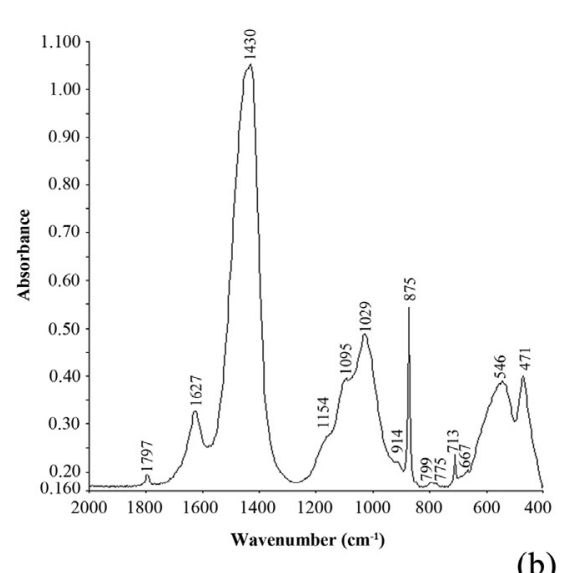

(b)
Fig. 7. BSE image (a), FT-IR spectrum (b) and XRD pattern (c) of red painting layers (S.2). (For interpretation of the references to colour in this figure legend, the reader is referred to the web version of this article.)

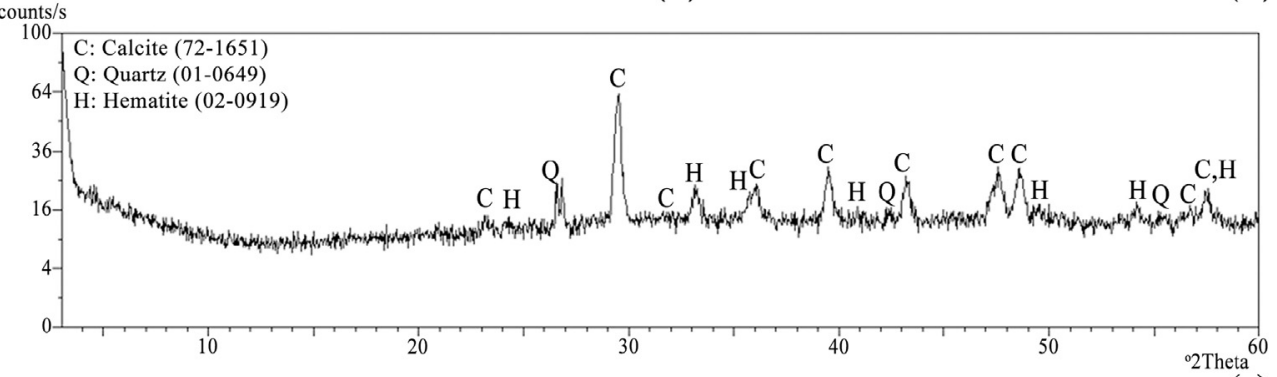

(c) 


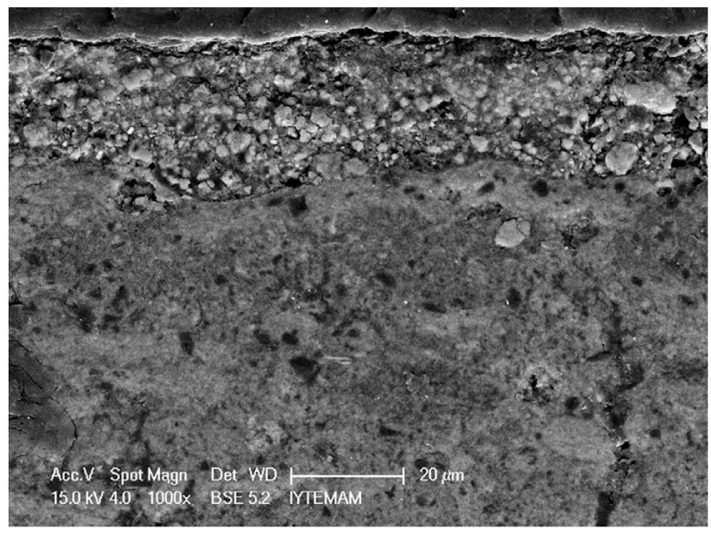

(a)

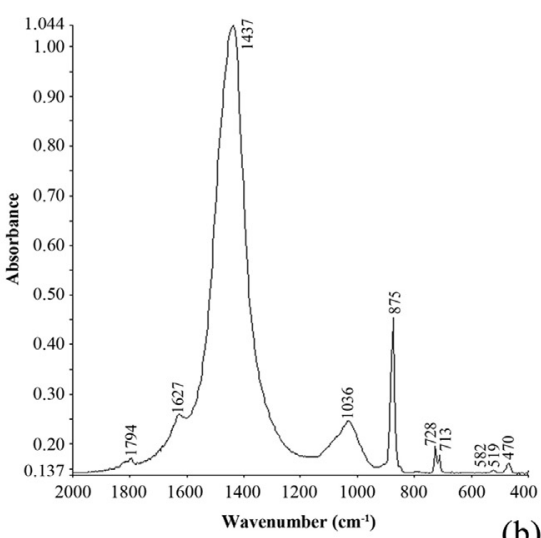

(b) counts/s

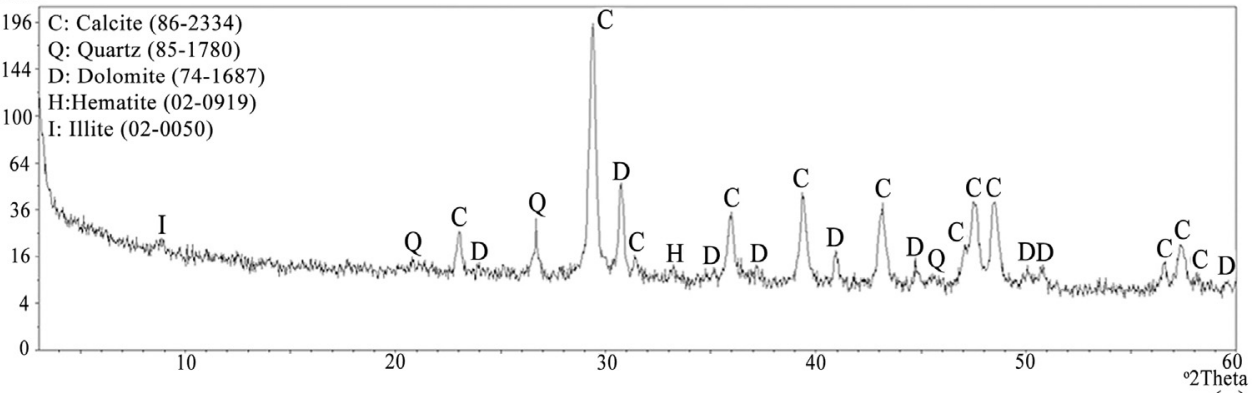

(c)
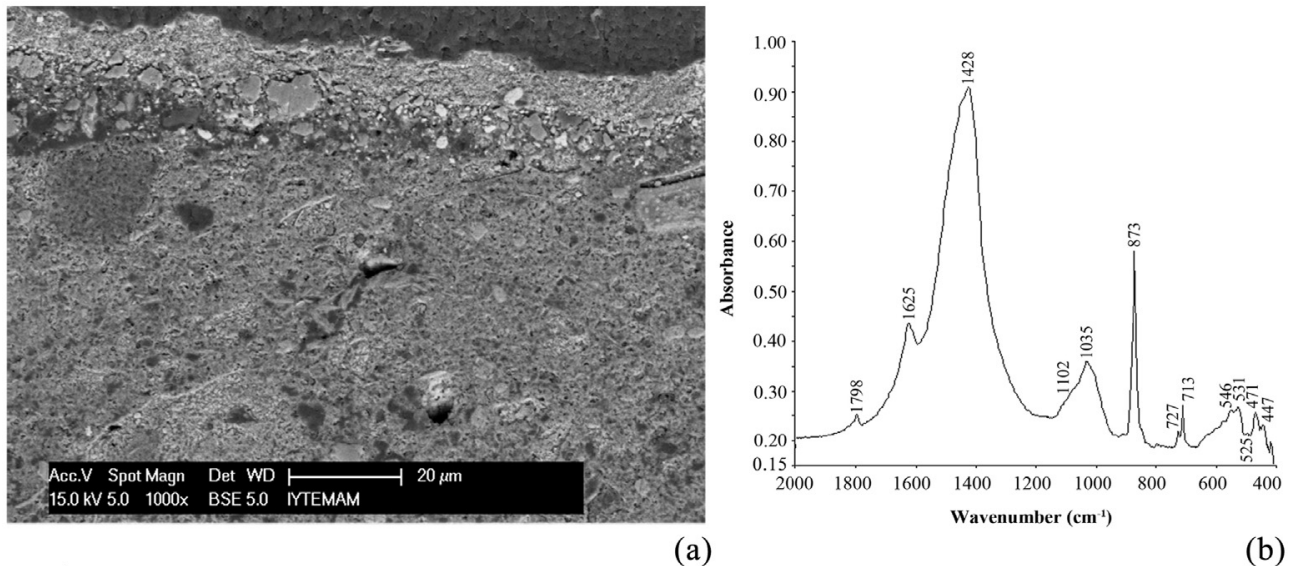

(a)

counts/s

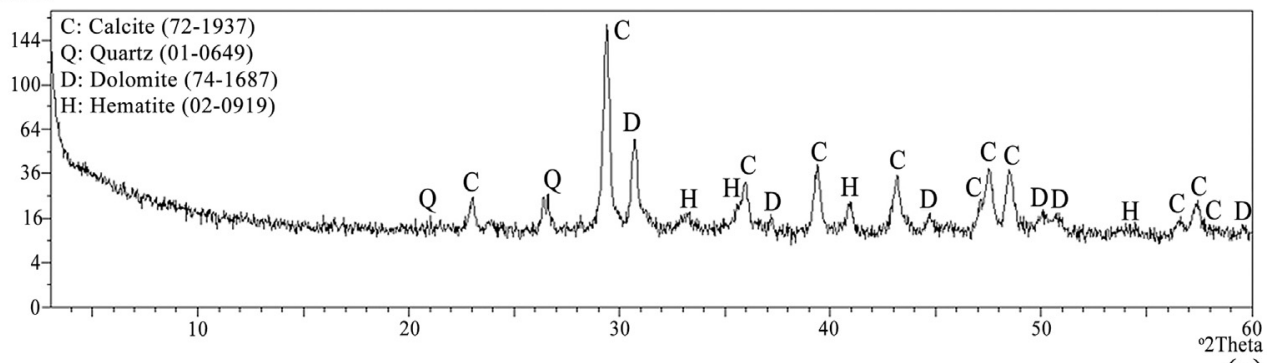

(c)
Fig. 8. BSE image (a), FT-IR spectrum (b) and XRD pattern (c) of yellow painting layers (S.3). (For interpretation of the references to colour in this figure legend, the reader is referred to the web version of this article.)
Fig. 9. BSE image (a), FT-IR spectrum (b) and XRD pattern (c) of purple painting layers (S.4). (For interpretation of the references to colour in this figure legend, the reader is referred to the web version of this article.)
$\mathrm{Si}$, $\mathrm{Na}$, and $\mathrm{K}$ due to presence of clay minerals were determined (Table 2).

The presence of iron in the composition of paint may indicate the use of iron-based purple ochre such as caput mortuum $\left(\mathrm{Fe}_{2} \mathrm{O}_{3}\right)$. Caput mortuum, most commonly used pigments in Byzantine wall paintings, was rare and expensive (Bikiaris et al., 2000; Daniilia et al., 2000; Marshall et al., 2005).

\subsubsection{Green colored painting}

SEM analysis indicated that green painting was executed on dry plaster layer with thickness of roughly $25 \mu \mathrm{m}$ (Fig. 10a). FT-IR analysis of the green paint layer showed typical bands of the calcite and dolomite at 2515, 1798, 1627, 1428, 873, 727 and $713 \mathrm{~cm}^{-1}$ (Fig. 10b). In addition to calcite and dolomite, strong bands of celadonite at 3558 , 1118, 971, 494, 454 and $439 \mathrm{~cm}^{-1}$ were also indicated in the FT-IR 

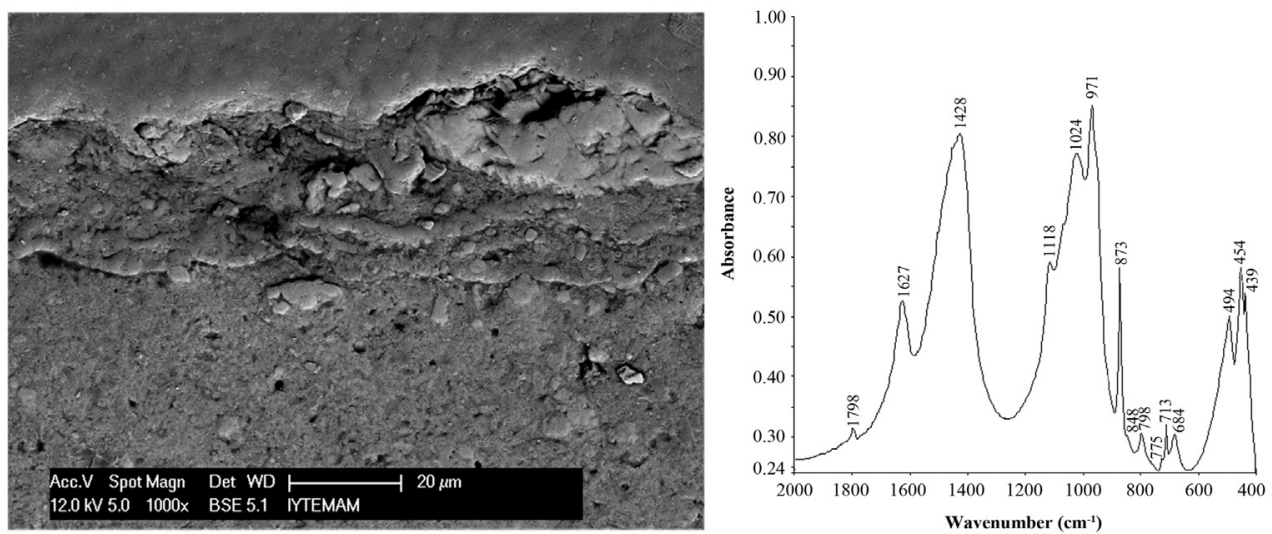

(a)

counts/s

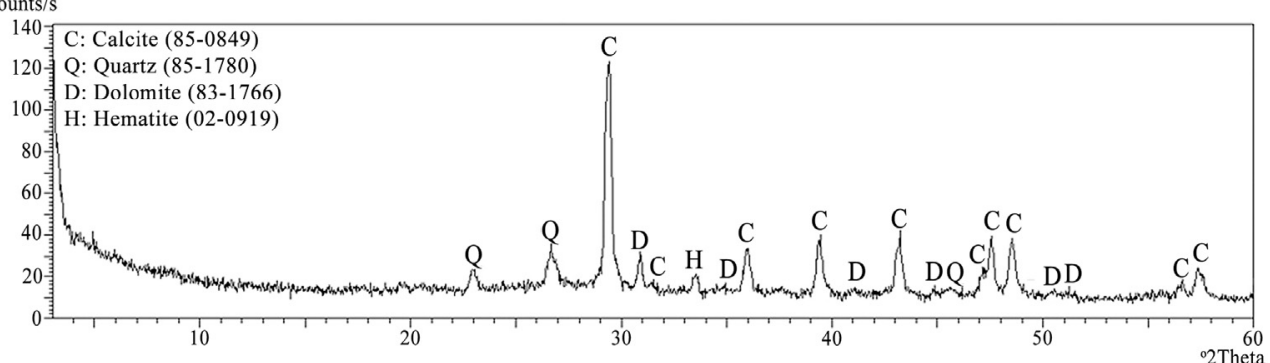

(c)
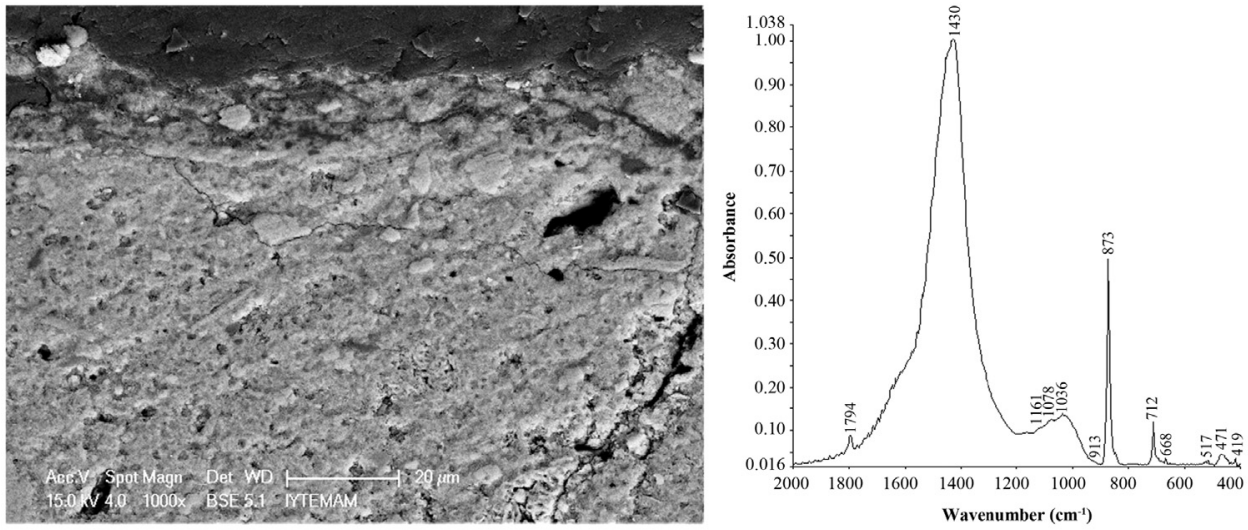

(a) (b) (b)
Fig. 10. BSE image (a), FT-IR spectrum (b) and XRD pattern (c) of green painting layers (S.5). (For interpretation of the references to colour in this figure legend, the reader is referred to the web version of this article.)

Fig. 11. BSE image (a), FT-IR spectrum (b) and XRD pattern (c) of dark blue painting layers (S.6) (For interpretation of the references to colour in this figure legend, the reader is referred to the web version of this article.)

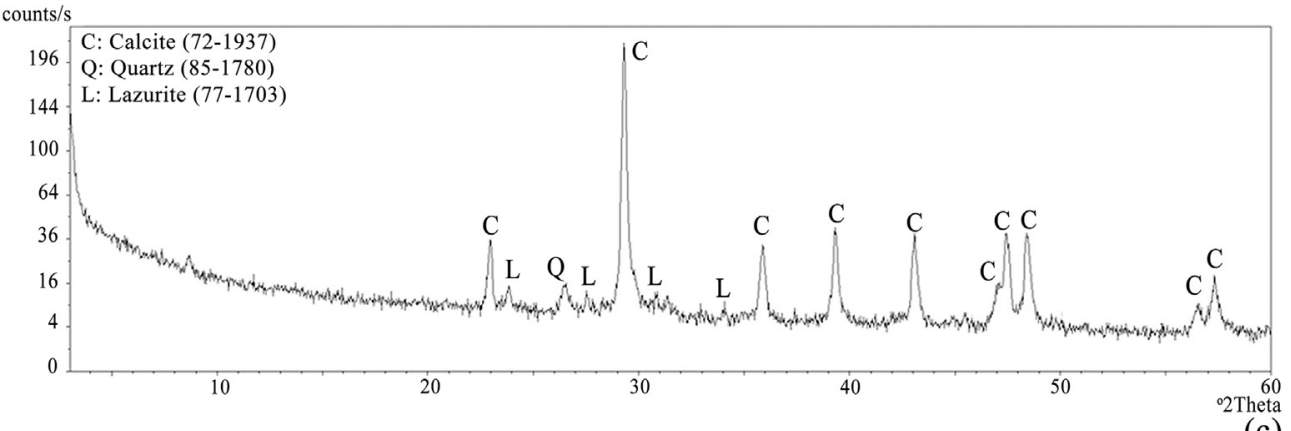

(c)

analysis (Fig. 10b). The XRD analysis carried out on surface of greenpainted plaster was indicated that it was mainly composed of calcite, dolomite, quartz and hematite (Fig. 10c). In the SEM-EDS analyses, high amount of calcium $(\mathrm{Ca})$ and magnesium $(\mathrm{Mg})$ due to carbonated lime binder and low amounts of iron (Fe), aluminium (Al) and silicon (Si) due to green pigment were indicated (Table 2).

When the results are considered as a whole, it can be said that dolomitic lime was used as binder and green earth (terre-verte) derived from celadonite $\left(\mathrm{K}\left(\mathrm{Mg}, \mathrm{Fe}^{2+}\right)\left(\mathrm{Fe}^{3+,} \mathrm{Al}\right) \mathrm{Si}_{4} \mathrm{O}_{10}(\mathrm{OH})\right.$ ) was used as green pigment. In some studies, the use of green earth was also indicated in historic mural paintings in Byzantine art (Daniilia et al., 2000; Daniilia et al., 2007; Hein et al., 2009; Pelosi et al., 2013; Pelosi et al., 2016). 


\subsubsection{Dark blue colored painting}

SEM analyses indicated that dark blue painting $(15 \mu \mathrm{m})$ was executed in lime-secco technique (Fig. 11a). In the FT-IR spectrum of dark blue paint sample, calcite bands at 2515, 1794, 1430, 873, $712 \mathrm{~cm}^{-1}$ and Si-O bands at $1161,1078,1036,668,517,462 \mathrm{~cm}^{-1}$ were indicated (Fig. 11b). The spectrum demonstrated the absorption bands at $1161,1078,1036,668$ and $471 \mathrm{~cm}^{-1}$ which could be indicative for the presence of lazurite (lapis lazuli) ((Na,Ca) $\left.)_{8}\left[(\mathrm{Al}, \mathrm{Si})_{12} \mathrm{O}_{24}\right]\left(\mathrm{S}, \mathrm{SO}_{4}\right)\right)$ (Gadsden, 1975; Hein et al., 2009). The infrared absorption bands at 517, $471 \mathrm{~cm}^{-1}$ could be attributed to the presence of hematite (Gadsden, 1975). FT-IR results were supported by XRD analysis. XRD spectrum of the dark blue paint has demonstrated that the painting layer contains basically calcite, lazurite, and quartz (Fig. 11c).In parallel with mineralogical analyses, the SEM-EDS analyses on dark bluishpainted sample were revealed the presence of mainly calcium $(\mathrm{Ca})$, silicon ( $\mathrm{Si}$ ), oxygen (O), aluminium ( $\mathrm{Al}$ ) and iron (Fe) (Table 2).

As a result of XRD, FT-IR and SEM-EDS analysis, lazurite (lapis lazuli) mineral was the main pigment of dark blue painting. Lapis lazuli was a precious pigment because it was expensive and rare. It was also often reserved for iconographically significant elements of wall paintings for similar reasons (Mora et al., 1984; Pelosi et al., 2013; Zorba et al., 2006).

\section{Conclusion}

Material characteristics of the Byzantine wall paintings in the church of the archaeological site at Anaia (Turkey) were investigated by using XRD, FT-IR spectroscopy, SEM-EDS and TGA analysis. The work supply useful information to enlarge the knowledge of the wall paintings executed in Byzantine churches built in Anatolia. The results of the analysis indicated that wall paintings were executed in lime-secco technique on dry lime-based fine plasters. In the execution of paintings, dolomitic lime was mixed with pigments and then applied on dry fine plaster layer. Iron and aluminosilicate-based pigments were generally used in the paintings. The pigments used were red ochre (hematite) in red, yellow ochre (goethite) in yellow, caput mortuum in purple, green earth (celadonite) in green and lazurite in blue paintings. The present study indicated that the techniques and materials used in the execution of wall paintings of Byzantine Church built in Anaia are nearly the same with the ones built in the other countries and also in other Byzantine contexts of Turkey.

\section{Acknowledgement}

The authors thank Prof. Dr. Zeynep Mercangöz for providing the painting samples. The authors thank also the researchers of the Centre for Materials Research at the İzmir Institute of Technology for XRD and SEM-EDS analyses during the experimental stage of this study.

\section{References}

Akdeniz, E., 2007. Kadıkalesi kazısı Miken buluntuları (Mycenaean findings from the excavations of Kadıkalesi). Arkeoloji Dergisi 1, 35-70 (in Turkish).
Bianchin, S., Casellato, U., Favaro, M., Vigato, P.A., Colombini, M.P., Gautier, G., 2008. Physico-chemical and analytical studies of the mural paintings at Kariye Museum of Istanbul. J. Cult. Herit. 9 (2), 179-183.

Bikiaris, D., Daniilia, S.X., Sotiropoulou, S., Katsimbiri, O., Pavlidou, E., Moutsatsou, A.P., Chryssoulakis, Y., 2000. Ochre-differentiation through micro-raman and micro-FTIR spectroscopies: application on wall paintings at Meteora and Mount Athos, Greece. Spectrochim. Acta A Mol. Biomol. Spectrosc. 56 (1), 3-18.

Brysbaert, A., 2008. Painted plaster from bronze age Thebes, Boeotia (Greece): a technological study. J. Archaeol. Sci. 35 (10), 2761-2769.

Chever, L., Pavia, S., Howard, R., 2010. Physical properties of magnesian lime mortars. Mater. Struct. 43 (1-2), 283-296.

Daniilia, S., Sotiropoulou, S., Bikiaris, D., Salpistis, C., Karagiannis, G., Chryssoulakis, Y., Priced, B.A., Carlsone, J.H., 2000. Panselinos' Byzantine wall paintings in the Protaton church, Mount Athos, Greece: a technical examination. J. Cult. Herit. 1 (2), 91-110.

Daniilia, S., Tsakalof, A., Bairachtari, K., Chryssoulakis, Y., 2007. The Byzantine wall paintings from the Protaton church on Mount Athos, Greece: tradition and science. J. Archaeol. Sci. 34 (12), 1971-1984.

Daniilia, S., Minopoulou, E., Andrikopoulos, K.S., Tsakalof, A., Bairachtari, K., 2008. From Byzantine to post-Byzantine art: the painting technique of St Stephen's wall paintings at Meteora, Greece. J. Archaeol. Sci. 35 (9), 2474-2485.

De Benedetto, G.E., Laviano, R., Sabbatini, L., Zambonin, P.G., 2002. Infrared spectroscopy in the mineralogical characterization of ancient pottery. J. Cult. Herit. 3 , $177-186$.

Gadsden, J.A., 1975. Infrared Spectra of Minerals and Related Inorganic Compounds. Butterworths, London.

Hein, A., Karatasios, I., Mourelatos, D., 2009. Byzantine wall paintings from Mani (Greece): microanalytical investigation of pigments and plasters. Anal. Bioanal. Chem. 395 (7), 2061-2071.

Hradil, D., Grygar, T., Hradilova, J., Bezdicka, P., 2003. Clay and iron oxide pigments in the history of painting. Appl. Clay Sci. 22 (5), 223-236.

Jeffreys, E., Haldon, J.F., Cormack, R., 2008. The Oxford Handbook of Byzantine Studies. Oxford University Press, Oxford, New York.

La Russa, M.F., Rovella, N., Pelosi, C., Rossi, D., Benucci, M., Romagnoli, G., Selva Bonino, V.E., Casoli, A., Ruffolo, S.A., 2016. A multi-analytical approach applied to the archaeometric study of mortars from the Forty Martyrs rupestrian complex in Cappadocia (Turkey). Microchem. J. 125, 34-42.

Marshall, L.J.R., Williams, J.R., Almond, M.J., Atkinson, S.D.M., Cook, S.R., Matthews, W., Mortimore, J.L., 2005. Analysis of ochres from Clearwell caves: the role of particle size in determining colour. Spectrochim. Acta A Mol. Biomol. Spectrosc. 61 (1-2), 233-241.

Mazzocchin, G.A., Orsega, E.F., Baraldi, P., Zannini, P., 2006. Aragonite in Roman wall paintings of the VIII ${ }^{\mathrm{a}}$ Regio, Aemilia, and X ${ }^{\mathrm{a}}$ Regio, Venetia et Histria. Ann. Chim. 96, 377-387.

Mercangöz, Z., Doğer, L., 2009. Kuşadası, Kadıkalesi/Anaia Bizans sırlı seramikleri. In: Türkmenoğlu, A.G. (Ed.), Proceedings of 1. ODTÜ Arkeometri Çalıștayı-Türkiye Arkeolojisinde Seramik ve Arkeometrik Çalışmaları-Prof. Dr. Ufuk Ersin Anısına. Metu Press, Ankara, pp. 83-101 (in Turkish).

Mora, P., Mora, L., Philippot, P., 1984. Conservation of Wall Paintings. Butterworths, London, Boston.

Pelosi, C., Agresti, G., Andaloro, M., Baraldi, P., Pogliani, P., Santamaria, U., 2013. The rock hewn wall paintings in Cappadocia (Turkey). Characterization of the constituent materials and a chronological overview, e Preservation. Science 10, 99-108.

Pelosi, C., Agresti, G., Andaloro, M., Baraldi, P., Pogliani, P., Santamaria, U., La Russa, M.F., Ruffolo, S.A., Rovella, N., 2016. Micro-Raman and micro-stratigraphic analysis of the painting materials in the rock-hewn church of the Forty Martyrs in Sahinefendi, Cappadocia (Turkey). Archaeometry 58 (4), 659-672.

Restle, M., 1969. Byzantine Wall Paintings in Asia Minor, Trans. I.R. Gibbons (Shannon, 1969); First Published as Die byzantinische Wandmalerei in Kleinasien (Recklinghausen, 1967).

RILEM Commission 25 PEM, 1980. Tests defining the structure. Mater. Struct. 13 (3), $177-181$.

Schwartzbaum, P.M., 1986. Conservation of the Mural Paintings in the Rock-cut Churches of Göreme. Appendix in Eibstein, A. W. Tokali Kilise: Tenth-century Metropolitan Art in Byzantine Cappadocia (pp 52-57). Dumbarton Oaks Research Library and Collection, Washington, DC.

Zorba, T., Pavlidou, E., Stanojlovic, M., Bikiaris, D., Paraskevopoulos, K.M., Nikolic, V., Nikolic, P.M., 2006. Technique and palette of XIIIth century painting in the monastery of Mileseva. Appl. Phys. Mater. Sci. Process. 83 (4), 719-725. 